\title{
AGE COMPOSITION, GROWTH, AND MORTALITY OF EUROPEAN HAKE MERLUCCIUS MERLUCCIUS (ACTINOPTERYGII: GADIFORMES: MERLUCCIIDAE) FROM THE NORTHERN AEGEAN SEA, TURKEY
}

\author{
Uğur UZER ${ }^{1 *}$, Bayram ÖZTÜRK², and Taner YILDIZ ${ }^{1}$ \\ ${ }^{1}$ Department of Fisheries Technology and Management, Faculty of Aquatic Sciences, Istanbul University, Istanbul, \\ Turkey \\ ${ }^{2}$ Department of Marine Biology, Faculty of Aquatic Sciences, Istanbul University, Istanbul, Turkey
}

Uzer U., Öztürk B., Yıldız T. 2019. Age composition, growth, and mortality of European hake Merluccius merluccius (Actinopterygii: Gadiformes: Merlucciidae) from the northern Aegean Sea, Turkey. Acta Ichthyol. Piscat. 49 (2): 109-117.

\begin{abstract}
Background. This study is the first attempt to acquire information about growth, age composition, and mortality of European hake, Merluccius merluccius (Linneaus, 1758), in the northern Aegean Sea. In Turkey, the hake is a very important commercial species captured with demersal trawls. Therefore the management of the hake fishery is important for the stock sustainability. The aim of this study was to determine the age composition, growth, and mortality of hake from Gökçeada Island, northern Aegean Sea, Turkey.

Materials and methods. A total of 2253 hake specimens were collected monthly in three fishing seasons off Gökçeada Island from September 2013 to April 2016 with a commercial trawler. Fish age was estimated based on otoliths. Growth parameters were calculated according to the von Bertalanffy growth equation.

Results. The total length ranged from $5.9 \mathrm{~cm}$ to $51.2 \mathrm{~cm}$ for all individuals. The length-weight relation was $W=0.0034 \mathrm{TL}^{3.2249}\left(R^{2}=0.9655\right)$. The age of the fish was estimated to range from 1 to 6 years. Growth parameters were as follows, $L_{\infty}=88.54 \mathrm{~cm}, k=0.1088, t_{0}=-0.9962$ for males, $L_{\infty}=102.34 \mathrm{~cm}, k=0.0908, t_{0}=-1.3105$ for females, and $L_{\infty}=102.66 \mathrm{~cm}, k=0.0992, t_{0}=-0.8085$ for all fish sampled. The total, natural, and fishing mortality ratio of the samples were found as $2.21,0.57$, and 1.64 , respectively.

Conclusion. The exploitation ratio $(E)$ of the samples was estimated to be 0.74 , showing a high fishing pressure on the hake population and it will be the main argument for the need of a strict management on the hake fishery in the area studied. The other argument is the high number of juveniles in the catch composition. It is expected that the results of the presently reported study will contribute to the sustainable fishery for hake. The minimum landing size in the Turkish waters should be increased from $20 \mathrm{~cm}$ to $25 \mathrm{~cm}$ to ensure at least single breeding of Merluccius merluccius.
\end{abstract}

Keywords: Merluccius merluccius, age, growth, mortality, northern Aegean Sea

\section{INTRODUCTION}

European hake, Merluccius merluccius (Linnaeus, 1758), is a commercially important demersal species, distributed in the eastern Atlantic Ocean from Norway and Iceland to Mauritania, and also in the Mediterranean Sea (Froese and Pauly 2018). Merluccius merluccius is generally found on muddy bottoms and distributed on a wide depth range from the coastline down to the depth of $1000 \mathrm{~m}$ (Cohen et al. 1990, Philips 2012). This species is mostly carnivorous, feeding on fishes, crustaceans, molluscs, algae, and plant detritus (Philips 2012). Hakes are found in a deeper zone in the daytime but move to the upper zone at night. (Froese and Pauly 2018). In the west European demersal fisheries, the European hake is one of the most heavily exploited fish species (Casey and Pereiro 1995), and is also an important predator of deeper shelf-upper slope Mediterranean communities (Carpentieri et al. 2005). European hake is generally caught by demersal trawls (especially by the bottom and beam trawls), pelagic trawls, longlines, and bottomset gillnets. The yearly global landings of the European hake was $125000 \mathrm{t}$ in 2014 (Anonymous 2016a) while the annual landings of this species in Turkey was $706 \mathrm{t}$ (Anonymous 2016b). European hake has been reported as one of the most important target species for trawlers in the Ionian and Aegean Seas (Katsanevakis et al. 2010). 
There is a minimum landing size (MLS) of $27 \mathrm{~cm}$ total length (TL) in the European Union (Anonymous 2011) and $20 \mathrm{~cm}$ for Turkish Seas (Anonymous 2016c) in order to protect the juveniles of the species.

The information on the age, growth, and reproduction of the species has an important role in the management and sustainable exploitation of the stock. Several authors have studied the age estimation and growth parameters of hake (Morales-Nin et al. 1998, Uçkun et al. 2000, Godinho et al. 2001, Piñeiro and Saínza 2003, de Pontual et al. 2006, Ismen et al. 2010, Murua 2010, Belcaid and Ahmed 2011, Gurbet et al. 2013, Costa 2013, , Khoufi et al. 2014, Philips 2014, Soykan et al. 2015). On the other hand, many studies on stock assessment, population dynamics, and spatial distribution of hake have been implemented by Aldebert and Recasens (1996), Orsi-Relini et al. (2002), Lleonart and Maynou (2003), Stergiou et al. (2003), Abella et al. (2005), Gurbet et al. (2013), Yalçın and Gurbet (2016).

Fisheries management is important for sustainable fisheries and needs updating for different fishing areas. This study aims to determine the growth parameters, age composition, and mortality rates of hake. The presently reported study is the first scientific project covering hake population dynamics in the region of Gökçeada Island, northern Aegean Sea. The result of the presently reported study is necessary for sustainable fisheries for the region.

\section{MATERIALS AND METHODS}

The European hake, Merluccius merluccius, is both commercially and ecologically important for Gökçeada Island where the study was conducted (Fig. 1). The fish sampled monthly by commercial trawlers, in three fishing seasons, between September 2013 and April 2016, and a total of 2253 specimens were collected. There is a fishery ban in the spring-summer months (May, June, July, and August) for trawlers. Therefore, the sampling was carried out by the same bottom trawler after obtaining a research collection permit from the competent authority (Tarım ve Orman Bakanlığ 1 ; (Ministry of Agriculture and Forestry).

A traditional demersal trawl gear was used during the sampling, featuring a 5.4-m codend made of knotted polyethylene with $44 \mathrm{~mm}$ diamond mesh size. The operation time was between the end of steel rope release and the start of haul retrieval, the hauling speed was 2.22.6 knots, and the hauling time changed between 1 to $5 \mathrm{~h}$, thus the hauling time was calculated as $1 \mathrm{~h}$.

Total length (TL) and total weight (TW) of the collected hake specimens were determined. The sex was determined macroscopically. The sagittal otoliths of the samples were removed for the age estimation. The otoliths were ground on one side with two different abrasive papers with 35.0 $\mu \mathrm{m}$ and $25.8 \mu \mathrm{m}$ median diameters (Ross and Hüssy 2013), cleaned with ethanol, and immersed in glycerine for the examination with a microscope (Leica DFC295 stereomicroscope with Leica S8APO LAS image analysis software). The fish age was determined by interpreting the growth rings on the otoliths as translucent and opaque rings. Otoliths were assessed by two independent readers through otolith readings without referring to any information except the date of capture and size. The age estimation of some otoliths was rejected because of readings did not coincide.

The length-weight relation (LWR) was calculated using the equation

$$
W=a \mathrm{TL}^{b},
$$

where $W$ is the total weight, TL is the total length, and $a$ and $b$ values are the parameters of the equation (Ricker 1973). Growth parameters were calculated according to the von Bertalanffy growth equation (Sparre and Venema 1992)

$$
L_{\mathrm{t}}=L_{\infty}\left[1-e^{-k\left(t-t_{0}\right)}\right]
$$

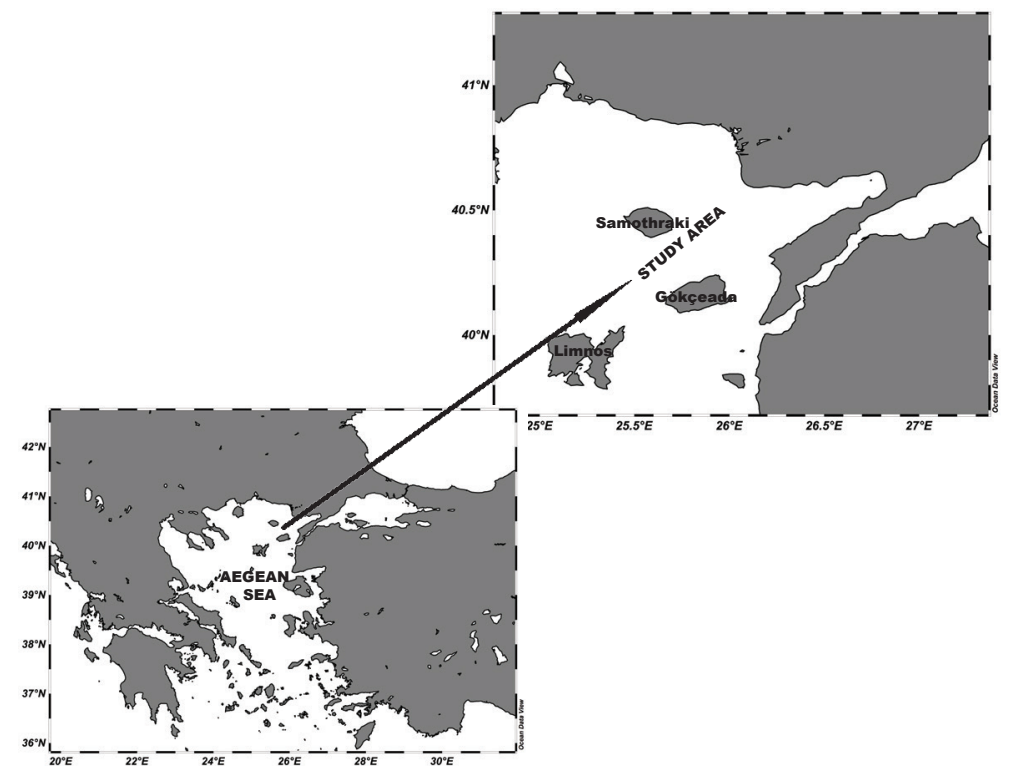

Fig. 1. The study area - Gökçeada Island, Turkey, northern Aegean Sea 
where $L_{\mathrm{t}}$ is the total length, $k$ is growth coefficient, $L_{\infty}$ is asymptotic length, $t_{0}$ is theoretical length at age zero, and $T$ is the mean water temperature.

The growth performance index $\left(\Phi^{\prime}\right)$ formulated by Pauly and Munro (1984) was also estimated for accuracy of the growth parameters

$$
\Phi^{\prime}=\log k+2 \cdot \log L_{\infty}
$$

The total mortality $(Z)$ was calculated from the agestructured catch curve formulated by Pauly et al. (1995). The natural mortality $(M)$ was estimated using the empirical equation described by Pauly (1980)

$\log (M)=0.8 \cdot \exp \left(-0.0152-0.279 \cdot \ln L_{\infty}+0.6543 \cdot\right.$ $\ln k+0.4630 \cdot \ln T$ )

The fishing mortality rate $(F)$ was estimated according to Sparre and Venema (1992)

$$
F=Z-M
$$

The exploitation rate $(E)$ was calculated by $F \cdot Z^{-1}$ (Pauly 1983).

The independent sample $t$-test was used for determining the possible significant difference in mean length between males and females. Additionally, analysis of covariance ANCOVA was used for determining significant difference between sexes to compare the parameter $b$ of LWR (Zar 1999). The SPSS 21.0 software package was used for statistical analyses and a significance level of 0.05 was adopted.

\section{RESULTS}

A total of 2253 European hake individuals were sampled monthly during the study period. The females constituted 31\% $(n=708)$, males constituted 50\% $(n=$ 1126), and the immature specimens constituted $18 \%(n=$ 419) of the total catch. The total length of all individuals ranged from $5.9 \mathrm{~cm}$ to $51.2 \mathrm{~cm}$ (mean \pm standard deviation: $25.4 \pm 0.11 \mathrm{~cm})$; the total weight was from 3.48 to $1162.89 \mathrm{~g}(160.29 \pm 2.99 \mathrm{~g})$. Furthermore, the TL of females was in between 19.1 and $51.2 \mathrm{~cm}(31.8 \pm 1.64$ $\mathrm{cm})$, males from 18.9 to $42.6 \mathrm{~cm}(30.5 \pm 1.47 \mathrm{~cm})$ (Fig. 2), and immature specimens from 5.9 to $22.1 \mathrm{~cm}$. The results of $t$-test indicated that there were significant differences $(P$ $<0.05$ ) in mean length between males and females.

The relation between total weight $(\mathrm{g})$ and total length (cm) values of male, female, and all fish are shown in Table 1 and Fig. 3 . The $a$ and $b$ values, obtained from the estimated length-weight relation equation were calculated as 0.0034 and 3.224, respectively and positive allometry growth was observed. The relation between the two variables was found to be insignificant $(P>0.001)$. In addition, the ANCOVA test showed that there were insignificant differences between the slopes $(b)$ estimated for females and males $(P>0.05)$.

The otolith structure of the European hake involves some false rings in the first year of growth. The false rings are larval rings which occur after the nucleus, hyaline rings occur in pelagic period and the rings occur when the fish got down to demersal zone (Godinho et al. 2001).

As shown in Fig. 4, the age estimation was based upon counting the number of annuli (rings) on 2253 otoliths. The length-at-age values and the number of individuals in each age class were presented in Table 2. Six age cohorts have been found from 1 to 6 years (Fig. 5). The most abundant age class was the 2nd, representing $45.05 \%$ of the fish, followed by the 3rd age class $(27.90 \%)$, the $1 \mathrm{st}$ age class $(25.44 \%)$, the 4 th age class $(1.48 \%)$, the 5 th age class $(0.09 \%)$, and the 6 th age class $(0.04 \%)$ (Figs. 6,7$)$.

The von Bertalanffy growth curve, shown in Fig. 8, represents all samples. In Table 3, the von Bertalanffy growth parameters were estimated for all sexes. It was visible that $L_{\infty}$ (asymptotic length) value of females (102.34 $\mathrm{cm})$ was relatively greater than that of males $(88.54 \mathrm{~cm})$; therefore, it is evident that the males grew slightly faster than the females.

The age-structured catch curve revealed that the total mortality rate $(Z)$ was estimated as 2.21 year $^{-1}$. The natural $(M)$ and fishing $(F)$ mortality rates were found to be 0.57 and 1.64 , respectively. In addition, the exploration ratio (E) was calculated as 0.74 .

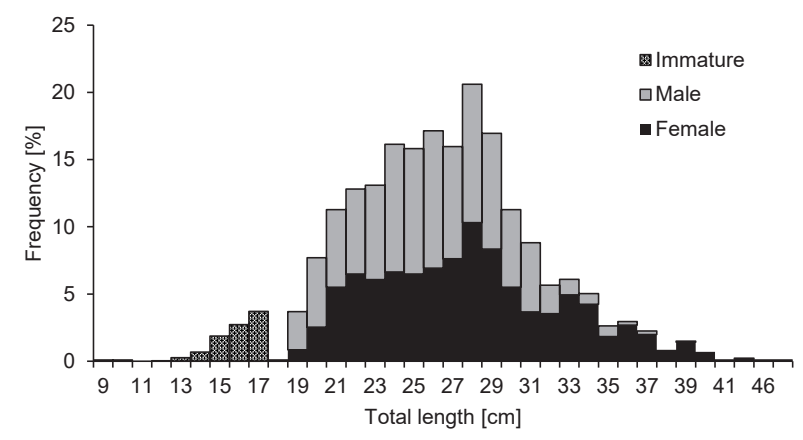

Fig. 2. Length-frequency distribution for females, males, and all samples of Merluccius merluccius from northern Aegean Sea, Turkey, studied within 2013-2016

Table 1

Length-weight relation parameters of Merluccius merluccius for all samples and their sexes from northern Aegean Sea, Turkey, studied within 2013-2016

\begin{tabular}{lccccc}
\hline \multirow{2}{*}{ Sex } & \multicolumn{2}{c}{ Regression factors } & & & \\
\cline { 2 - 3 } & $a$ & $b$ & Confidence limits of $b$ & Growth type & $r^{2}$ \\
\hline Female & 0.0041 & 3.1733 & $3.11-3.23$ & + Allometry & 0.9342 \\
Male & 0.0043 & 3.1454 & $3.09-3.19$ & + Allometry & 0.9250 \\
All samples & 0.0034 & 3.2249 & $3.20-3.25$ & + Allometry & 0.9655 \\
\hline
\end{tabular}

$a=$ intercept, $b=$ slope of the relation; $r^{2}=$ coefficient of determination. 


\section{DISCUSSION}

This study is the first attempt on age composition,
anth, and mortality of Merluccius merluccius from Gökçeada Island, northern Aegean Sea. As given in Table 4, the length range of specimens in this study was generally similar to those of other studies. In addition, the $a$ and $b$ values of the LWR in the study were generally similar to those of other studies.

The age and growth parameters of M. merluccius are presented by several authors (Table 5). The parameters of the studies could show variations according to the sampling period, study area, and environmental conditions.
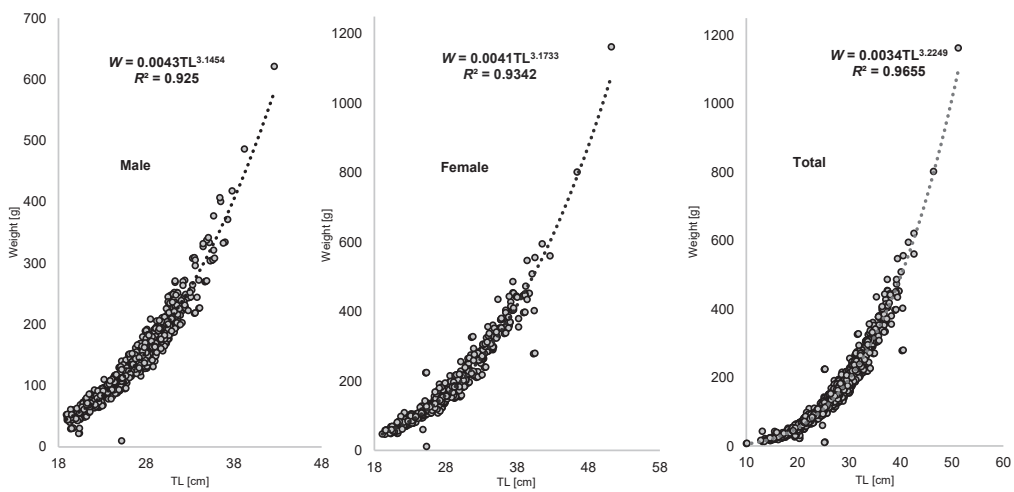

Fig. 3. Length-weight relation for male, female, and all samples of Merluccius merluccius from northern Aegean Sea, Turkey, studied within 2013-2016
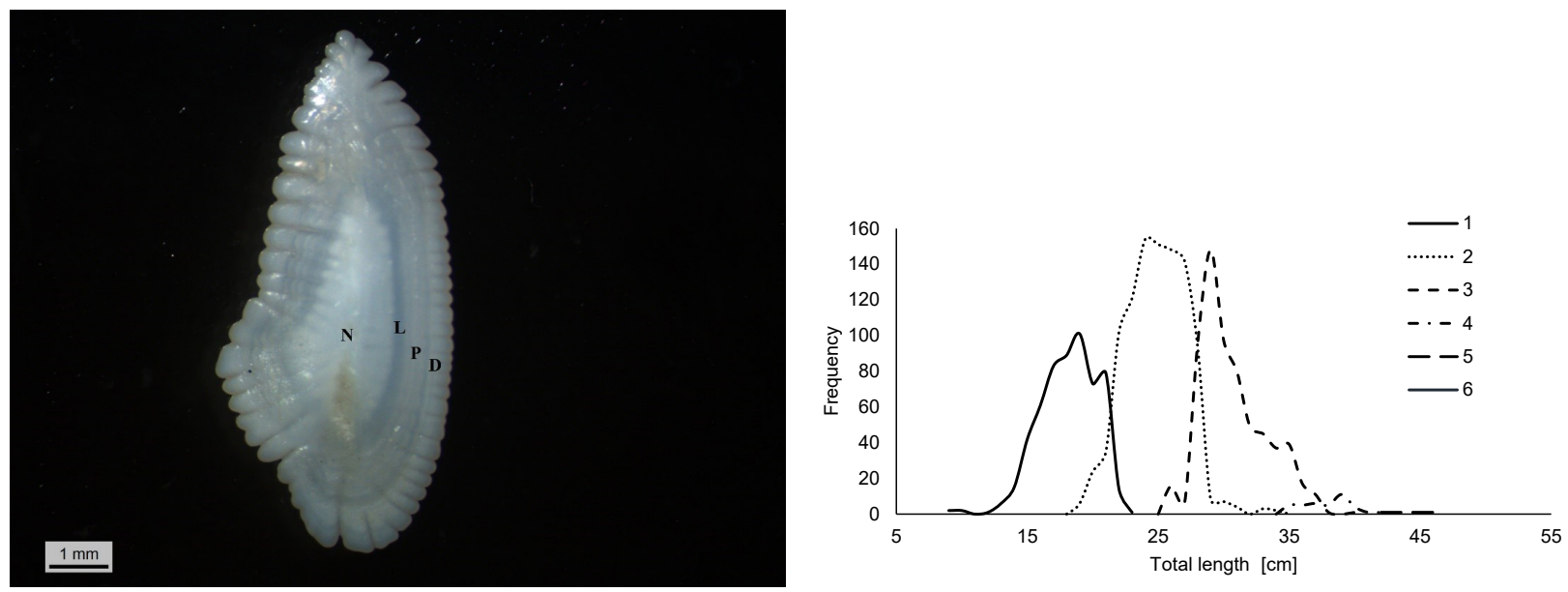

Fig. 4. Sagittal otolith of Merluccius merluccius showing the rings; $\mathrm{N}=$ nucleus, $\mathrm{L}=$ larval ring, $\mathrm{P}=$ hyaline ring, $\mathrm{D}=$ demersal ring

Fig. 5. The age cohort of Merluccius merluccius from northern Aegean Sea, Turkey, studied within 20132016
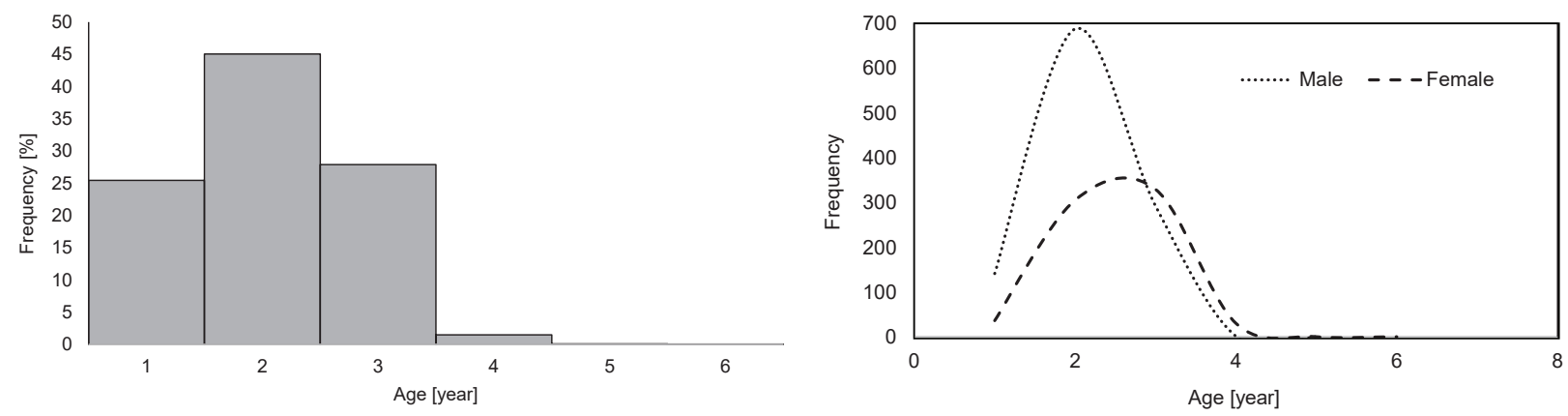

Fig. 6. Age frequency distribution of Merluccius merluccius from northern Aegean Sea, Turkey, studied within 2013-2016

Fig. 7. The sex-specific age distribution of Merluccius merluccius from northern Aegean Sea, Turkey, studied within 2013-2016 
Table 2

Length-at-age key for all samples of Merluccius merluccius from northern Aegean Sea, Turkey, studied within 2013-2016

\begin{tabular}{|c|c|c|c|c|c|c|c|}
\hline \multirow{2}{*}{$\begin{array}{l}\text { Total length } \\
{[\mathrm{cm}]}\end{array}$} & \multicolumn{7}{|c|}{ Number of fish in age groups } \\
\hline & 1 & 2 & 3 & 4 & 5 & 6 & Total \\
\hline 9 & 2 & & & & & & 2 \\
\hline 10 & 2 & & & & & & 2 \\
\hline 11 & & & & & & & 0 \\
\hline 12 & 1 & & & & & & 1 \\
\hline 13 & 6 & & & & & & 6 \\
\hline 14 & 15 & & & & & & 15 \\
\hline 15 & 42 & & & & & & 42 \\
\hline 16 & 61 & & & & & & 61 \\
\hline 17 & 83 & & & & & & 83 \\
\hline 18 & 89 & & & & & & 89 \\
\hline 19 & 101 & 6 & & & & & 107 \\
\hline 20 & 73 & 24 & & & & & 97 \\
\hline 21 & 79 & 35 & & & & & 114 \\
\hline 22 & 14 & 102 & & & & & 116 \\
\hline 23 & 1 & 121 & & & & & 122 \\
\hline 24 & & 154 & & & & & 154 \\
\hline 25 & & 151 & & & & & 151 \\
\hline 26 & & 148 & 16 & & & & 164 \\
\hline 27 & & 142 & 6 & & & & 148 \\
\hline 28 & & 94 & 95 & & & & 189 \\
\hline 29 & & 8 & 148 & & & & 156 \\
\hline 30 & & 7 & 97 & & & & 104 \\
\hline 31 & & 4 & 80 & & & & 84 \\
\hline 32 & & & 49 & & & & 49 \\
\hline 33 & & 3 & 45 & & & & 48 \\
\hline 34 & & 2 & 37 & & & & 39 \\
\hline 35 & & & 39 & 5 & & & 44 \\
\hline 36 & & & 17 & 5 & & & 22 \\
\hline 37 & & & 11 & 6 & & & 17 \\
\hline 38 & & & 1 & 5 & & & 6 \\
\hline 39 & & & & 11 & & & 11 \\
\hline 40 & & & 1 & 4 & & & 5 \\
\hline 41 & & & & 1 & & & 1 \\
\hline 42 & & & & 1 & 1 & & 2 \\
\hline 46 & & & & & 1 & & 1 \\
\hline 51 & & & & & & 1 & 1 \\
\hline Total & 569 & 1001 & 642 & 38 & 2 & 1 & 2253 \\
\hline
\end{tabular}

Several researchers have evaluated the von Bertalanffy growth parameters according to different seasons and areas as well (Table 5). The growth parameters varied respectively to the environmental and ecological factors. The differences in the growth parameters in fish are affected by the genetic structure, temperature, nutrition, and diseases (Pauly 1994, Wootton 1998). In addition, the population parameters can be affected and changed year by year with the recruitment and environment factors (Burton et al. 2012). The growth variation ( $k$ ) of the European hake in the presently reported study was between 0.09 and 0.10 .

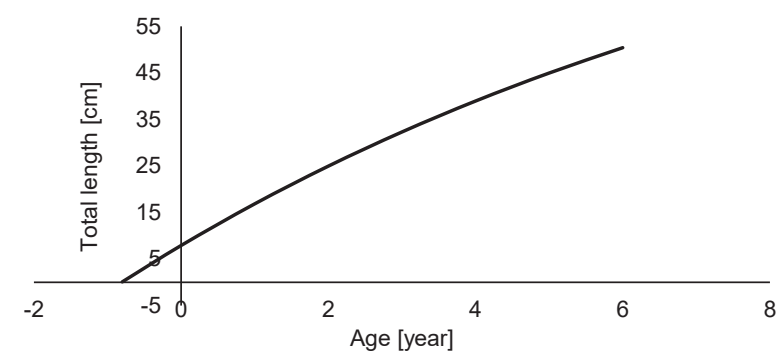

Fig. 8. The von Bertalanffy growth curve for all samples of Merluccius merluccius from northern Aegean Sea, Turkey, studied within 2013-2016

Table 3

The von Bertalanffy growth parameters calculated for Merluccius merluccius from northern Aegean Sea, Turkey, studied within 2013-2016

\begin{tabular}{lrrrrc}
\hline \multirow{2}{*}{ Sex } & \multicolumn{5}{c}{ Parameter } \\
\cline { 2 - 6 } & \multicolumn{1}{c}{$L_{\infty}$} & \multicolumn{1}{c}{$k$} & \multicolumn{1}{c}{$t_{0}$} & \multicolumn{1}{c}{$W_{\infty}$} & $\Phi^{\prime}$ \\
\hline Female & 102.34 & 0.0908 & -1.3105 & 9800.8 & 2.97 \\
Male & 88.54 & 0.1088 & -0.9962 & 5738.2 & 2.93 \\
Both sexes & 102.66 & 0.0992 & -0.8085 & 10424.0 & 3.01 \\
\hline
\end{tabular}

$L_{\infty}=$ asymptotic mean length, $k=$ growth rate, $t_{0}=$ hypothetic age at zero length, $W_{\infty}=$ asymptotic mean weight, $\Phi^{\prime}=$ growth performance index values.

The growth parameters $\left(L_{\infty}, t_{0}\right.$, and $\left.k\right)$ were compared with the other authors (Table 5 ). The asymptotic length $\left(L_{\infty}\right)$ is similar to the studies from the Gulf of Lions (Aldebert and Recasens 1996), North-east Atlantic (Godinho et al. 2001), Alicante Bay (García-Rodríguez and Esteban 2002), and the Sea of Marmara (Kahraman et al. 2017). However, the lower $L_{\infty}$ values than those in the presently reported study were from Bay of Biscay (de Pontual et al. 2006), the Moroccan North Atlantic Ocean (Belcaid and Ahmed 2011), the Egyptian Mediterranean (Philips 2014), and the Turkish coasts of the central Aegean Sea (Gurbet et al. 2013, Soykan et al. 2015). The value of $L_{\infty}$ for males $(88.54 \mathrm{~cm})$ was lower than the value for females $(102.34 \mathrm{~cm})$, showing that the growth of the females was faster than the males. As for $k$ and $t_{0}$ values, the results of this study are in line with those of the other studies (Godinho et al. 2001, Kahraman et al. 2017). At the end, the growth performance index $\left(\Phi^{\prime}\right)$ show similarities and greater from the other studies, show lower values than the study in the Egyptian Mediterranean (Philips 2014). Furthermore, according to the mentioned studies, the $\Phi^{\prime}$ value shows a significant difference ( $t$-test; $P<0.05$ ) (Table 5)

The main factors affecting the length-weight relation are temperature, salinity, habitat, depth, maturity stages, nutrient, fishing season, sampling methodology, fishing gear selectivity, and genetic variations (Ricker 1969, Bagenal and Tesch 1978, Recasens et al. 1998, Basilone et al. 2006, Froese 2006, Domínguez-Petit et al. 2010, Soykan et al. 2010).

Gurbet et al. (2013) reported that the mortality rates $(Z, M$, and $F)$ and exploitation ratio $(E)$ were calculated 
Table 4

The length-weight relation parameters for Merluccius merluccius in different areas

\begin{tabular}{lrcccl}
\hline \multicolumn{1}{c}{ Study area } & $n$ & Total length $[\mathrm{cm}]$ & $a$ & $b$ & \multicolumn{1}{c}{ Reference } \\
\hline Aegean Sea, central, Turkey & 336 & $13.6-43.5$ & 0.005 & 3.194 & Uçkun et al. 2000 \\
Aegean Sea, central, Turkey & 2711 & $2.7-48.8$ & 0.981 & 3.189 & Özaydın et al. 2007 \\
Aegean Sea, central, Turkey & 1353 & $5.9-44.4$ & - & - & Gurbet et al. 2013 \\
Aegean Sea, central, Turkey & 2108 & $5.2-45.5$ & 0.00341 & 3.24 & Soykan et al. 2015 \\
Aegean Sea, Greece & 152 & $18.0-50.2$ & 0.004 & 3.2 & Moutopoulos and Stergiou 2002 \\
Aegean Sea, northern, Turkey & 22 & $19.7-41.1$ & 0.005 & 3.103 & Karakulak et al. 2006 \\
Aegean Sea, northern, Turkey & 2041 & $7.9-66.0$ & 0.004 & 3.150 & Ismen et al. 2007 \\
Aegean Sea, northern, Turkey & 2253 & $5.9-51.2$ & 0.0034 & 3.224 & This study \\
Atlantic, Bay of Biscay & 1681 & $37.0-92.0$ & - & - & Murua and Motos 2006 \\
Atlantic, Portugal & 4935 & $7.3-93.3$ & 0.0038 & 3.172 & Costa 2013 \\
Atlantic, Spain, Portugal & 1391 & $6.0-78.0$ & 0.00733 & 2.981 & Piñeiro and Saínza 2003 \\
Mediterranean, Egypt & 229 & $14.0-43.0$ & - & - & Philips 2014 \\
Mediterranean, Gulf of Lions & 242 & $15.0-40.0$ & - & - & Mellon-Duval et al. 2010 \\
Sea of Marmara, Turkey & 777 & $10.4-53.3$ & 0.0079 & 2.989 & Kahraman et al. 2017 \\
\hline
\end{tabular}

$a=$ intercept, $b=$ slope of the relation.

Table 5

The von Bertalanffy growth parameters and growth performance index values obtained from different areas for Merluccius merluccius

\begin{tabular}{|c|c|c|c|c|c|c|c|}
\hline Study area & Method & Sex & $L_{\infty}$ & $k$ & $t_{0}$ & $\Phi^{\prime}$ & Reference \\
\hline Aegean Sea, central, Turkey & Otolith & $q+\hat{o}$ & 57.05 & 0.320 & - & - & Gurbet et al. 2013 \\
\hline Aegean Sea, central, Turkey & Otolith & $q+\hat{0}$ & 54.53 & 0.315 & -0.223 & 2.97 & Soykan et al. 2015 \\
\hline Aegean Sea, northern, Turkey & Otolith & $q+\hat{o}$ & 102.66 & 0.099 & -0.808 & 3.01 & This study \\
\hline Atlantic-Med, Strait of Gibraltar & Otolith & $q+\hat{0}$ & 80.80 & 0.350 & -1.700 & 3.36 & Piñeiro and Saínza 2003 \\
\hline Atlantic, Bay of Biscay & Otolith & $q+\hat{0}$ & 89.90 & 0.362 & - & - & de Pontual et al. 2006 \\
\hline Atlantic, North-east & Otolith & $q+\hat{o}$ & 110.60 & 0.089 & -0.970 & 2.99 & Godinho et al. 2001 \\
\hline Atlantic, North, Morocco & FISAT (ELEFAN) & $q+\hat{0}$ & 72.45 & 0.280 & -0.720 & 3.16 & Belcaid and Ahmed 2011 \\
\hline Mediterranean, Alicante Bay, Spain & FISAT (ELEFAN) & $q+\hat{0}$ & 108.00 & 0.210 & -0.115 & 3.39 & García-Rodríguez and Esteban 2002 \\
\hline Mediterranean, Egypt & Otolith & $q+\hat{o}$ & 74.19 & 0.119 & -0.281 & 2.82 & Philips 2014 \\
\hline Mediterranean, Gulf of Lions & Otolith & q & 100.70 & 0.124 & -0.350 & - & Aldebert and Recasens 1996 \\
\hline Mediterranean, Gulf of Lions & Otolith & $0^{\lambda}$ & 72.80 & 0.149 & -0.383 & - & Aldebert and Recasens 1996 \\
\hline Sea of Marmara, Turkey & Otolith & $q+\hat{o}$ & 103.97 & 0.087 & -0.926 & 2.97 & Kahraman et al. 2017 \\
\hline
\end{tabular}

$L_{\infty}=$ asymptotic mean length, $k=$ growth rate, $t_{0}=$ hypothetic age at zero length, $\Phi^{\prime}=$ growth performance index values.

as $2.24 y^{-1}, 0.58 y^{-1}, 1.66 y^{-1}$, and 0.74 , respectively in the Turkish coasts of the central Aegean Sea, while the mortality rates $(Z, M$, and $F)$ were calculated as were $Z=$ $1.539 y^{-1}, M=0.579 y^{-1}, F=0.959 y^{-1}$, and $E=0.624$ in the same area (Soykan et al. 2015). High fishing pressure was determined due to the mortality rates of the presently reported study and the most abundant individuals being two years old in the catch composition.

The General Fisheries Commission for the Mediterranean (GFCM) has considered that European hake stocks in the Mediterranean are overexploited (growth and danger of recruitment overexploitation) with current fishing mortality $(F)$ which is about six times higher than the limit and target reference points (Anonymous 2016a). In addition, this species has been assessed as Least Concern category in IUCN Red List of Threatened Species, and subpopulations in the Mediterranean were previously assessed as Vulnerable due to declines in abundance attributed to high fishing pressure in the region (Fernandes et al. 2016).

Implementing the first minimum landing size (MLS) of the M. merluccius in the Turkish seas was in 1997 and the MLS for this species was $25 \mathrm{~cm}$ total length. Although there is no quota implementation in Turkey, the minimum landing size of the European hake was reduced from $25 \mathrm{~cm}$ to $20 \mathrm{~cm}$ total length by fishery legislation authority in 2016 for four years period (2016 to 2020) (Anonymous 2016c). Philips (2014) indicated that if it is needed, European hake to breed at least once, the minimum landing size must be $25 \mathrm{~cm}$ total length. The minimum landing size is $20 \mathrm{~cm}$ total length in the other Mediterranean European countries while for Atlantic regions, the MLS for European hake is $27 \mathrm{~cm}$ of total length and there is an annual quota for the total allowable catch. Under the lights of our findings, the European hake stock has to be investigated in the Turkish coast of Aegean Sea and management strategy must be 
changed into the quota system (TAC) as in the European Union countries.

The goal of the presently reported study was to investigate the length distribution, length-weight relation, age, growth and mortality of European hake in the north Aegean Sea and compare the findings with the other studies. Fishing fleets have been targeting European hake for a long time in the Mediterranean. As demonstrated in the presently reported study, there is high fishing pressure on this species and it is therefore recommended that strict management measures should be employed. Being a shared stock, European hake cooperation would be in progress between Turkey and Greece in the Aegean Sea for this commercially valuable species. In this case, further studies must be carried out in the future and it is expected that the results of the presently reported study will contribute to better fisheries management for European hake.

\section{ACKNOWLEDGEMENTS}

We would like to acknowledge the funding provided for the project (No: 32627) from the Scientific Research Projects Unit of Istanbul University and to thank the commercial trawl fishermen who helped us to collect the fish samples.

\section{REFERENCES}

Abella A., Serena F., Ria M. 2005. Distributional response to variations in abundance over spatial and temporal scales for juveniles of European hake (Merluccius merluccius) in the western Mediterranean Sea. Fisheries Research 71 (3): 295-310. DOI: 10.1016/j.fishres.2004.08.036

Aldebert Y., Recasens L. 1996. Comparison of methods for stock assessment of European hake (Merluccius merluccius) in the Gulf of Lions (northwestern Mediterranean). Aquatic Living Resources 9 (1): 1322. DOI: $10.1051 /$ alr:1996003

Anonymous 2011. Regulation (EU) 579/2011 of the European Parliament and of the Council of 8 June 2011 amending Council Regulation (EC) No 850/98 for the conservation of fishery resources through technical measures for the protection of juveniles of marine organisms and Council Regulation (EC) No 1288/2009 establishing transitional technical measures from 1 January 2010 to 30 June 2011. Official Journal of the European Union L165: 1-2.

Anonymous 2016a. Merluccius merluccius (Linneaus, 1758). Species Fact Sheets. Fisheries and Aquaculture Department. FAO, Rome. http://www.fao.org/fishery/ species/2238/en

Anonymous 2016b. Su Ürünleri İstatistikleri. [Fisheries statistics.] Türkiye İstatistik Kurumu Başkanlığg (TÜIKK). [Turkish Statistical Institute.] Ankara, Turkey. http://www.tuik.gov.tr/PreTablo.do?alt_id=1005

Anonymous 2016c. Denizlerde ve İçsularda Ticari Amaçlı Su Ürünleri Avcılığını Düzenleyen 2/1 Numaralı Tebliğ, 2016-2020 Balıkçılık Sezonu No: $4 / 1$. [Fisheries regulation for marine and fresh waters for commercial fishery, 2016-2020 fishing period No. 4/1.] Gida Tarım ve Hayvancılık Bakanlığı, Su
Ürünleri Koruma ve Kontrol Genel Müdürlüğü, Ankara. [Ministry of Food, Agriculture and Livestock of Turkey, Protect and Control General Office, Ankara.] [In Turkish.]

Bagenal T.B., Tesch F.W. 1978. [Chapter 5] Age and growth. Pp. 101-136. In: Bagenal T.B. (ed.) Methods for assessment of fish production in fresh waters. 3rd edn. IBP Handbook No. 3. Blackwell Scientific Publication, Oxford, UK.

Basilone G., Guisande C., Patti B., Mazzola S., Cuttitta A., Bonanno A., Vergara A.R., Maneiro I. 2006. Effect of habitat conditions on reproduction of the European anchovy (Engraulis encrasicolus) in the Strait of Sicily. Fisheries Oceanography 15 (4): 271 280. DOI: 10.1111/j.1365-2419.2005.00391.x

Belcaid S., Ahmed M.S. 2011. Growth, mortality and exploitation of European hake Merluccius merluccius in the Moroccan North Atlantic Sea. The Egyptian Journal of Aquatic Research 37 (2): 139-145.

Burton M.L, Potts J.C., Carr D.R. 2012. Age, growth and natural mortality of rock hind, Epinephelus adscensionis, from the Gulf of Mexico. Bulletin of Marine Science 88 (4): 903-917. DOI: 10.5343/ bms.2011.1102

Carpentieri P., Colloca F., Cardinale M., Belluscio A., Ardizzone G.D. 2005. Feeding habits of European hake (Merluccius merluccius) in the central Mediterranean Sea. Fishery Bulletin 103 (2): 411-416.

Casey J., Pereiro J. 1995. [Chapter five] European hake (M. merluccius) in the North-east Atlantic. Pp. 125147. DOI: 10.1007/978-94-011-1300-7 5 In: Alheit J., Pitcher T.J. (eds.) Hake; fisheries, ecology and markets. Fish and Fisheries Series, Vol. 15. Chapman and Hall, London, UK. DOI: 10.1007/978-94-011-1300-7

Cohen D.M., Inada T., Iwamoto T., Scialabba N. 1990. FAO species catalogue. Vol. 10. Gadiform fishes of the world (Order Gadiformes). An annotated and illustrated catalogue of cods, hakes, grenadiers and other gadiform fishes known to date. FAO Fisheries Synopsis No. 125. FAO, Rome.

Costa A.M. 2013. Somatic condition, growth and reproduction of hake, Merluccius merluccius L., in the Portuguese coast. Open Journal of Marine Science 3 (1): 12-30. DOI: 10.4236/ojms.2013.31002

de Pontual H., Groison A.L., Piñeiro C., Bertignac M. 2006. Evidence of underestimation of European hake growth in the Bay of Biscay, and its relationship with bias in the agreed method of age estimation. ICES Journal of Marine Science 63 (9): 1674-1681. DOI: 10.1016/j.icesjms.2006.07.007

Domínguez-Petit R., Saborido-Rey F., Medina I. 2010. Changes of proximate composition, energy storage and condition of European hake (Merluccius merluccius, L. 1758) through the spawning season. Fisheries Research 104 (1-3): 73-82. DOI: 10.1016/j. fishres.2009.05.016

Fernandes P., Cook R., Florin A.B., Lorance P., Nedreaas K.2016. Merlucciusmerluccius. TheIUCNRed List of Threatened Species 2016: e.T198562A84946555. 
[Downloaded on 26 October 2016.] DOI: 10.2305/IUCN. UK.2016-1.RLTS.T198562A84946555.en

Froese R. 2006. Cube law, condition factor and weightlength relationships: History, meta-analysis, and recommendations. Journal of Applied Ichthyology 22 (4): 241-253. DOI: 10.1111/j.1439-0426.2006.00805.x

Froese R., Pauly D. (eds.) 2018. FishBase. [Version 06/2018] http://www.fishbase.org

García-Rodríguez M., Esteban A. 2002. How fast does hake grow? A study on the Mediterranean hake (Merluccius merluccius L.) comparing whole otoliths readings and length frequency distribution data. Scientia Marina 66 (2): 145-156. DOI: 10.3989/ scimar.2002.66n2145

Godinho M.L., Afonso M.H., Morgado C. 2001. Age and growth of hake Merluccius merluccius L. 1758, from the northeast Atlantic (ICES division IXa). Boletín. Instituto Español de Oceanografía 17 (3-4): 255-262.

Gurbet R., Akyol O., Yalçın E. 2013. Exploitation and mortality rates of European hake (Merluccius merluccius) in the Aegean Sea (Izmir Bay, Turkey). Journal of Applied Ichthyology 29 (3): 569-572. DOI: 10.1111/jai.12082

Ismen A., Ozen E., Altinagac U., Ozekinci U., Ayaz A. 2007. Weight-length relationships of 63 fish species in Saros Bay, Turkey. Journal of Applied Ichthyology 23 (6): 707-708. DOI: 10.1111/j.1439-0426.2007.00872.x

Kahraman A.E., Yıldız T., Uzer U., Karakulak F.S. 2017. Age composition, growth and mortality of European hake Merluccius merluccius (Linnaeus, 1758) (Actinopterygii: Merlucciidae) from the Sea of Marmara, Turkey. Acta Zoologica Bulgarica 69 (3): 377-384.

Karakulak F.S., Erk H., Bilgin B. 2006. Length-weight relationships for 47 coastal fish species from the Northern Aegean Sea, Turkey. Journal of Applied Ichthyology 22 (4): 274-278. DOI: 10.1111/j.14390426.2006.00736.x

Katsanevakis S., Maravelias C.D., Vassilopoulou V. 2010. Otter trawls in Greece: Landing profiles and potential métiers. Mediterranean Marine Science 11 (1): 43-59. DOI: $10.12681 / \mathrm{mms} .90$

Khoufi W., Dufour J.L., Jaziri H., Elfehri S., Elleboode R., Bellamy E., Ben Meriem S., Romdhane M.S., Mahé K. 2014. Growth estimation of Merluccius merluccius off the northern coast of Tunisia. Cybium 38 (1): 53-59.

Lleonart J., Maynou F. 2003. Fish stock assessments in the Mediterranean: State of the art. Scientia Marina 67 (Suppl. 1): 37-49.

Mellon-Duval C., de Pontual H., Métral L., Quemener L. 2010. Growth of European hake (Merluccius merluccius) in the Gulf of Lions based on conventional tagging. ICES Journal of Marine Science 67 (1): 6270. DOI: 10.1093/icesjms/fsp215

Morales-Nin B., Torres G.J., Lombarte A., Recasens L. 1998. Otolith growth and age estimation in the
European hake. Journal of Fish Biology 53 (6): 11551168. DOI: $10.1006 /$ jfbi.1998.0781

Moutopoulos D.K., Stergiou K.I. 2002. Length-weight and length-length relationships of fish species from the Aegean Sea (Greece). Journal of Applied Ichthyology 18 (3): 200-203. DOI: 10.1046/j.14390426.2002.00281.x

Murua H. 2010. [Chapter two] The biology and fisheries of European hake, Merluccius merluccius, in the North-east Atlantic. Pp. 97-154. In: Lesser M. (ed.) Advances in Marine Biology Vol. 58. DOI: 10.1016/ B978-0-12-381015-1.00002-2

Murua H., Motos L. 2006. Reproductive strategy and spawning activity of the European hake, Merluccius merluccius (L.), in the Bay of Biscay. Journal of Fish Biology 69 (5): 1288-1303. DOI: 10.1111/j.10958649.2006.01169.x

Orsi-Relini L., Papaconstantinou C., Juckic-Peladic S., Souplet A., Gil de Sola L., Piccinetti C., Kavadas S., Rossi M. 2002. Distribution of the Mediterranean hake populations (Merluccius merluccius smiridus Rafinesque, 1810) (Osteichthyes: Gadiformes) based on six years monitoring by trawl-surveys: Some implications for management. Scientia Marina 66 (Suppl. 2): 21-38. DOI: 10.3989/scimar.2002.66s221

Özaydın O., Uçkun D., Akalın S., Leblebici S., Tosunoğlu Z. 2007. Length-weight relationships of fishes captured from Izmir Bay, central Aegean Sea. Journal of Applied Ichthyology 23 (6): 695-696. DOI: 10.1111/j.1439-0426.2007.00853.x

Pauly D. 1980. On the interrelationships between natural mortality, growth parameters, and mean environmental temperature in 175 fish stocks. Journal du Conseil international pour l'Exploration de la Mer 39 (2): 175-192. DOI: 10.1093/icesjms/39.2.175

Pauly D. 1983. Some simple methods for the assessment of tropical fish stocks. FAO Fisheries Technical Paper No. 234.

Pauly D. 1994. Quantitative analysis of published data on the growth, metabolism, food consumption, and related features of the red-bellied piranha, Serrasalmus nattereri (Characidae). Environmental Biology of Fishes 41 (1-4): 423-437. DOI: 10.1007/BF02197858

Pauly D., Moreau J., Abad N. 1995. Comparison of agestructured and length converted catch curves of brown trout Salmo trutta in two French rivers. Fisheries Research 22 (3-4): 197-204. DOI: 10.1016/01657836(94)00323-O

Pauly D., Munro J.L. 1984. Once more on growth comparison in fish and invertebrates. Fishbyte 2 (1): 21.

Philips A.E. 2012. Feeding behavior of the European hake Merluccius merluccius Linnaeus, 1758 (Family: Gadidae) from Egyptian Mediterranean waters off Alexandria. The Egyptian Journal of Aquatic Research 38 (1): 39-44. DOI: 10.1016/j.ejar.2012.09.002

Philips A.E. 2014. Age composition of the European hake Merluccius merluccius, Linnaeus, 1758 from the Egyptian Mediterranean waters of Alexandria. The 
Egyptian Journal of Aquatic Research 40 (2): $163-$ 169. DOI: $10.1016 /$ j.ejar.2014.06.002

Piñeiro C., Saínza M. 2003. Age estimation, growth and maturity of the European hake (Merluccius merluccius (Linnaeus, 1758)) from Iberian Atlantic waters. ICES Journal of Marine Science 60 (5): 1086-1102. DOI: 10.1016/S1054-3139(03)00086-9

Recasens L., Lombarte A., Morales-Nin B., Torres G.J. 1998. Spatiotemporal variation in the population structure of the European hake in the NW Mediterranean. Journal of Fish Biology 53 (2): 387401. DOI: $10.1111 /$ j.1095-8649.1998.tb00988.x

Ricker W.E. 1969. Effects of size-selective mortality and sampling bias on estimates of growth, mortality, production, and yield. Journal of the Fisheries Research Board of Canada 26 (3): 479-541. DOI: 10.1139/f69-051

Ricker W.E. 1973. Linear regressions in fishery research. Journal of the Fisheries Research Board of Canada 30 (3): 409-434. DOI: 10.1139/f73-072

Ross S.D., Hüssy K. 2013. A reliable method for ageing of whiting Merlangius merlangus for use in stock assessment and management. Journal of Applied Ichthyology 29 (4): 825-832. DOI: 10.1111/jai.12204

Soykan O., İlkyaz A.T., Metin G., Kınacıgil H.T. 2010. Growth and reproduction of blotched picarel (Spicara maena Linneaus, 1758) in the central Aegean Sea, Turkey. Turkish Journal of Zoology 34 (4): 453-459. DOI: 10.3906/zoo-0903-29
Soykan O., İlkyaz A.T., Metin G., Kınacıgil H.T. 2015. Age, growth and reproduction of European hake (Merluccius merluccius (Linn., 1758)) in the Central Aegean Sea, Turkey. Journal of the Marine Biological Association of the United Kingdom 95 (4): 829-837. DOI: $10.1017 /$ S002531541400201X

Sparre P., Venema S.C. 1992. Introduction to tropical fish stock assessment. Part I: Manual. FAO Fisheries Technical Paper No: 306/1, Rev 1. FAO, Rome.

Stergiou K.I., Machias A., Somarakis S., Kapantagakis A. 2003. Can we define target species in Mediterranean trawl fisheries? Fisheries Research 59 (3): 431-435. DOI: $10.1016 / \mathrm{S} 0165-7836(02) 00016-4$

Uçkun D., Toğulga M., Taşkavak E. 2000. A preliminary study on the growth of the common hake (Merluccius merluccius L., 1758) in Izmir Bay, Aegean Sea. Acta Adriatica 41 (2): 25-34.

Wootton R.J. 1998. Ecology of teleost fishes. 2nd edn., Kluwer Academic Publishers, Fish and Fisheries Series 24, Dordrecht, Boston, London.

Yalçın E., Gurbet R. 2016. Environmental influences on the spatio-temporal distribution of European Hake (Merluccius merluccius) in Izmir Bay, Aegean Sea. Turkish Journal of Fisheries and Aquatic Sciences 16 (1): 1-14. DOI: 10.4194/1303-2712-v16_1_01

Zar J.H. 1999. Biostatistical analysis. 4th edn. Prentice Hall, Upper Saddle River, NJ, USA.

Received: 11 May 2018 Accepted: 23 November 2018 Published electronically: 15 June 2019 